
\title{
$\angle S$ Research Square \\ Facilitators and barriers to self-monitoring of blood glucose (SMBG) in diabetic patients visiting family medicine clinics at Akuh.
}

\section{Asif Hakim Brohi}

Aga Khan University Hospital

\section{Arsalan Hakim}

Shaheed Montarma Benazir Bhutto Medical University

\section{Muhammad Khan}

Pir Abdul Qadir Shah Jeelani Institute of Medical Sciences

\section{Ehsanullah Malik}

Shaheed Montarma Benazir Bhutto Medical University

\section{Delijan Mugheri}

Shaheed Montarma Benazir Bhutto Medical University

\section{Fozia Shaikh}

Shaheed Montarma Benazir Bhutto Medical University

\section{Waseem Abbas ( $\nabla$ waseemmalhani@yahoo.com )}

Shaheed Mohtarma Benazir Bhutto Medical University

\section{Nadeem Baloch}

Shaheed Montarma Benazir Bhutto Medical University

\section{Zehra Ashraf}

Jinnah University for Women

\section{Altaf Ali Mangi}

Gomal University Faculty of Pharmacy

\section{Saika Lashari}

Shah Abdul Latif University

\section{Research article}

Keywords: T2DM, self-monitoring blood glucose (SMBG), facilitators to SMBG, barriers of SMBG

Posted Date: June 30th, 2020

DOI: https://doi.org/10.21203/rs.3.rs-35708/v1 
License: (c) (i) This work is licensed under a Creative Commons Attribution 4.0 International License. Read Full License 


\section{Abstract}

BACKGROUND: To determine factors that facilitate and are barriers to self-monitoring of blood glucose in type 2 diabetic patients visiting family medicine clinics at a tertiary care teaching hospital Karachi Pakistan.

METHODS: Approximately 255 patients were consecutively recruited from the clinics during April 2018 to May 2019 at Family Medicine outpatient clinics at the Aga Khan University Hospital. Data on sociodemographic status, facilitators and barriers to SMBG were extracted through a questionnaire, after obtaining an informed written consent. Data was entered and analyzed in SPSS version 19.

RESULTS: Among study participants $47.5 \%$ were above 50 years and $51.4 \%$ were males. About $30.2 \%$ of the participants were practicing SMBG at least once a month and $26 \%$ were practicing it daily. Fear of complications was the biggest facilitator (80.1\%) and being expensive (51.4\%) was barrier for SMBG. Over half of the SMBG practicing participants (59.7\%) were diagnosed with diabetes for more than 05 years (p: 0.63).

CONCLUSION: Assessment of blood glucose is a critical component of diabetes treatment and management. It can motivate patients to become active participants in their own care. Health care providers should communicate and educate the patients about the advantages of SMBG.

\section{Background}

It is one of the most common diseases worldwide; the prevalence of this chronic disease is increasing at an alarming rate, as economic development and urbanization lead to changing lifestyles characterized by reduced physical activity, and increased obesity(1).

According to the International Diabetic Federation (IDF) report 2017, globally 425 million people have DM; this figure will reach to 629 million by the year 2045(2). About 1 in 11 adults worldwide now have DM and it is the ninth major cause of death worldwide $(2,3)$. About $12 \%$ of global health expenditure is spent on diabetes ( $\$ 727$ billion). One third of the people with diabetes are living in low and middle-income countries and approximately $90 \%$ of them have type 2 diabetes mellitus (T2DM) $(4,5)$

Despite of amazing advances in both basic and clinical medical sciences, DM is still an incurable lifelong disease with an ever so increasing health care costs. Its incidence is rising all over the world especially in the Middle East and South Asian countries $(1,6)$. Asia is considered to be center of this epidemic disease. Asian countries contribute more than $60 \%$ of world's diabetic population and prevalence of this disease is increasing in these countries $(7,8)$. India and china have substantial numbers of people with diabetes and by year 2025 each will have 20 million affected people (4).

SMBG has been found to be effective modality for better control of diabetes. SMBG became a standard of care in 1993 when the Diabetes Control and Complications Trial (DCCT) demonstrated that intensive 
treatment to achieve meticulous glycemic control could prevent the onset and slow the progression of long-term micro vascular complications(9). Furthermore, several trials have shown that frequent SMBG is correlated with improvements in metabolic control (10-12). Given the evidence in favor of tight glycemic control, the current practice guidelines recommend that SMBG be carried out at least three times per day in patients with type 1 diabetes mellitus (13).

SMBG has become a principal component of intensive diabetes management allowing for rapid and accurate assessment and treatment of glycaemia (6). SMBG is an effective tool that enables patients and healthcare providers to tailor therapy to maintain near-normal glycaemia, minimizing hypo- and hyperglycemia, which is a fundamental element of diabetes care $(6,14)$. Despite SMBG being highly recommended in people with diabetes using insulin its utilization remains low (15). In the United States of America and Italy, It was found that only a minority of those with diabetes using insulin $(26 \%$ and $13.9 \%$, respectively) practiced daily SMBG, even though the monitoring devices are provided free in Italy (15). In Asian countries, such as Korea, only $32 \%$ of people with type 2 diabetes were shown to practice SMBG regularly $(15,16)$, and in China, $39.5 \%$ of those with type 2 diabetes were shown to practice SMBG at least once monthly(17).

\section{Methods}

\section{STUDY SETTING:}

Data was collected from outpatient family medicine clinics (OPD's) at Aga Khan University Hospital Pakistan (AKUH). AKUH is located in the Karachi city, which is the main economic and cultural hub of Pakistan. The hospital is ISO and JCIA certified.

\section{DURATION OF STUDY:}

\section{One Year and one month from April 2018 to May 2019.}

\section{SAMPLE SIZE:}

Sample size was calculated with WHO software for sample size determination. It was calculated on the basis of facilitators and barriers of SMBG and their percentage of SMBG usage. Based on these values, with $95 \%$ confidence interval and bound on error of $5 \%$ the sample size came out to be 227 at $21 \%$. After addition of $10 \%$ of non-responders the final sample size was approximately 255 study participants.

Formula For Sample Size Calculation: (see Formula in the Supplementary Files)

\section{SAMPLING TECHNIQUE:}

A non-probability Consecutive sampling was used.

\section{INCLUSION CRITERIA:}


All diabetics' patients from age 18 years to 60 years and were on any oral hypoglycemic and/or insulin were included.

\section{EXCLUSION CRITERIA:}

Those who do not give consent, or were terminally ill and those with psychiatric problems (for example dementia, mental retardation) were excluded.

\section{Study Design}

This study was cross sectional

\section{DATA COLLECTION PROCEDURE:}

Patients fulfilling the inclusion criteria were included in the study as mentioned above was questioned by well-developed questionnaire. Written informed consent was taken from the study participants. The consent described the purpose of this study, its risk, benefits, and right to refusal and withdrawal from study, without any prejudice.

\section{ETHICAL CONSIDERATION:}

The study was approved by an Institutional Ethical Review Committee of the Aga Khan University.

\section{PLAN OF ANALYSIS:}

Data was double entered and analyzed in SPSS version 19.0. Baseline information was analyzed using descriptive statistics. Frequencies and proportions were reported for categorical variables such as age, gender, educational status, and the perceived Facilitators to self-monitoring of blood glucose (desire to see the effect of dietary changes, desire to please the physician, family motivation, afraid of the complications of Diabetes, good patient information and education, doctor patient communication, setting glycemic targets with patients, financial support and experiencing hypoglycemic symptoms). Frequencies and proportions were also be reported for the Barriers to SMBG (test strip handling issues, pain, lack of motivation, not convinced it was necessary, did not think there was a need, did not have enough time for regular SMBG, cost issues, not having all the equipment needed for the test, finding it cumbersome to carry all the things needed to test, testing as frequently as they think they should because of lack of time). The outcome variables were Facilitators and Barriers to SMBG. Frequency and percentages of all questions related to Facilitators and Barriers to SMBG among type II diabetic patients were calculated. Chi-square test was applied to observe relation of various socio demographic variables (age, gender, monthly income, time since diagnosis of diabetes) with barriers and facilitators as mentioned above. Moreover, stratification was done on potential effect modifiers such as (age, gender, time since diagnosis of diabetes) to see their effect on SMBG. All the analysis were two tailed and Pvalue of 0.05 was considered statistically significant. 


\section{Results}

A total of 300 diabetics were approached from the clinics out of which 255 patients agreed to participate in the study. The overall response rate was found to be $85 \%$. Majority of the patients were above 50 years of age $(n=121,47.5 \%)$ and the lowest proportion of the participants were between 20 to 35 years of age $(n=21,8.2 \%)$. Among study participants, the proportion of male participants $(n=131,51.4 \%)$ were slightly higher than the female participants $(n=124,48.6 \%)$. Moreover, majority of the participants were married $(n=193,75.7 \%)$ and majority had education till intermediate level. In the study sample majority of the study participants ( $n=116,45.4 \%$ ) had an average household monthly income between PKR 20,000 to PKR 50,000. Approximately $62 \%(n=158)$ of the participants were diagnosed with diabetes for more than 05 years.

Table 1 shows the barriers to SMBG as responded by the study participants. A similar proportion of the participants believed that SMBG is not convenient (51\%) and also very expensive (51.4\%). Similarly, about $51 \%$ also reported that SMBG is only necessary when one is experiencing hypoglycemic symptoms.

The facilitators to SMBG as described by the study participants are presented in Table 2. Almost similar proportion of the participants replied that SMBG is done to see the dietary changes (50.6\%). About $53.3 \%$ and $51.8 \%$ of the participants responded that SMBG performed to please physician and a major facilitator to SMBG is family motivation, respectively.

As for as The relationship of Sociodemographic variables with SMBG is concerned, Out of the $30 \%$ who practiced SMBG, most of them were more than 50 years of age $(n=39,50.6 \%)$, and were males $(n=41$, $53.2 \%$ ). About $36.2 \%$ of the participants who had their average monthly household income between PRK $50,000$ to 100,000 (p: 0.97), were practicing SMBG and over half of the participants ( $n=46,59.7 \%)$ who had been diagnosed with diabetes for more than 05 years were practicing SMBG (p: 0.63).

Table 1

Frequency of barriers to SMBG among study participants

\begin{tabular}{|lll|}
\hline Barriers & $\begin{array}{l}\text { Number } \\
(\mathrm{n}=255)\end{array}$ & $\begin{array}{l}\text { Percentage } \\
\end{array}$ \\
\hline Testing is not convenient & 130 & $51.0 \%$ \\
\hline Strips and needles for blood sugar monitoring is too expensive & 131 & $51.4 \%$ \\
\hline Testing is too painful & 134 & $52.5 \%$ \\
\hline Cannot perform blood sugar test due to advanced age & 125 & $49.0 \%$ \\
\hline Testing is only necessary when experiencing hypoglycemic symptoms & 130 & $51.0 \%$ \\
\hline
\end{tabular}


Table 2

Facilitators to SMBG among study participants

\begin{tabular}{|l|cc|}
\hline Variables & $\begin{array}{l}\text { Number } \\
(n=\end{array}$ & Percentage \\
& $255)$ & \\
\hline SMBG is done because of experiencing hypoglycemic symptoms & 135 & $52.9 \%$ \\
\hline SMBG is done to see the effect of dietary changes in blood glucose & 129 & $50.6 \%$ \\
\hline SMBG is done to please your physician & 136 & $53.3 \%$ \\
\hline SMBG is done because of family motivation & 132 & $51.8 \%$ \\
\hline $\begin{array}{l}\text { You think people do SMBG as they are afraid of the complications of } \\
\text { Diabetes }\end{array}$ & 205 & $80.1 \%$ \\
\hline
\end{tabular}


Table 3

STRATIFICATION OF POTENTIAL CONFOUNDERS AND BARRIERS TO SMBG:

\begin{tabular}{|c|c|c|c|c|c|}
\hline Variables & $\begin{array}{l}\text { Inconvenient } \\
\mathrm{n}(\%)\end{array}$ & $\begin{array}{l}\text { Expensive } \\
\mathrm{n}(\%)\end{array}$ & $\begin{array}{l}\text { Painful n } \\
(\%)\end{array}$ & $\begin{array}{l}\text { Can't } \\
\text { do it } \\
\text { age } \\
\text { n (\%) }\end{array}$ & $\begin{array}{l}\text { Necessary in hypoglycemic } \\
\text { condition } \\
\mathrm{n}(\%)\end{array}$ \\
\hline \multicolumn{6}{|c|}{ Age of Participants } \\
\hline 21 to 35 & $\begin{array}{l}10 \\
(7.7 \%)\end{array}$ & $\begin{array}{l}11 \\
(8.4 \%)\end{array}$ & $\begin{array}{l}10 \\
(7.5 \%)\end{array}$ & $\begin{array}{l}7 \\
(5.6 \%)\end{array}$ & $\begin{array}{l}10 \\
(7.7 \%)\end{array}$ \\
\hline 36 to 50 & $\begin{array}{l}61 \\
(46.9 \%)\end{array}$ & $\begin{array}{l}56 \\
(42.7 \%)\end{array}$ & $\begin{array}{l}59 \\
(44.0 \%)\end{array}$ & $\begin{array}{l}57 \\
(45.6 \%)\end{array}$ & $\begin{array}{l}52 \\
(40.0 \%)\end{array}$ \\
\hline $\begin{array}{l}\text { More than } \\
50\end{array}$ & $\begin{array}{l}59 \\
(45.4 \%)\end{array}$ & $\begin{array}{l}64 \\
(48.9 \%)\end{array}$ & $\begin{array}{l}65 \\
(48.5 \%)\end{array}$ & $\begin{array}{l}61 \\
(48.8 \%)\end{array}$ & $\begin{array}{l}68 \\
(52.3 \%)\end{array}$ \\
\hline P-value & 0.690 & 0.874 & 0.871 & 0.324 & 0.283 \\
\hline Gender & & & & & \\
\hline Male & $\begin{array}{l}61 \\
(46.9 \%)\end{array}$ & $\begin{array}{l}65 \\
(49.6 \%)\end{array}$ & $\begin{array}{l}69 \\
(51.5 \%)\end{array}$ & $\begin{array}{l}68 \\
(54.4 \%)\end{array}$ & $\begin{array}{l}69 \\
(53.1 \%)\end{array}$ \\
\hline Female & $\begin{array}{l}69 \\
(53.1 \%)\end{array}$ & $\begin{array}{l}66 \\
(50.4 \%)\end{array}$ & $\begin{array}{l}65 \\
(48.5 \%)\end{array}$ & $\begin{array}{l}57 \\
(45.6 \%)\end{array}$ & $\begin{array}{l}61 \\
(46.9 \%)\end{array}$ \\
\hline P-value & 0.147 & 0.565 & 0.968 & 0.343 & 0.579 \\
\hline Educational S & tus & & & & \\
\hline $\begin{array}{l}\text { Not } \\
\text { educated }\end{array}$ & $\begin{array}{l}13 \\
(10.0 \%)\end{array}$ & $\begin{array}{l}16 \\
(12.2 \%)\end{array}$ & $\begin{array}{l}10 \\
(7.5 \%)\end{array}$ & $\begin{array}{l}10 \\
(8.0 \%)\end{array}$ & $\begin{array}{l}12 \\
(9.2 \%)\end{array}$ \\
\hline Primary & $\begin{array}{l}12 \\
(9.2 \%)\end{array}$ & $\begin{array}{l}13 \\
(9.9 \%)\end{array}$ & $\begin{array}{l}14 \\
(10.4 \%)\end{array}$ & $\begin{array}{l}20 \\
(16.0 \%)\end{array}$ & $\begin{array}{l}20 \\
(15.4 \%)\end{array}$ \\
\hline Secondary & $\begin{array}{l}39 \\
(30.0 \%)\end{array}$ & $\begin{array}{l}38 \\
(29.0 \%)\end{array}$ & $\begin{array}{l}40 \\
(29.9 \%)\end{array}$ & $\begin{array}{l}36 \\
(28.8 \%)\end{array}$ & $\begin{array}{l}33 \\
(25.4 \%)\end{array}$ \\
\hline Intermediate & $\begin{array}{l}47 \\
(36.2 \%)\end{array}$ & $\begin{array}{l}41 \\
(31.3 \%)\end{array}$ & $\begin{array}{l}49 \\
(36.6 \%)\end{array}$ & $\begin{array}{l}39 \\
(31.2 \%)\end{array}$ & $\begin{array}{l}40 \\
(30.8 \%)\end{array}$ \\
\hline
\end{tabular}

$P$ value: Chi square $p$ - value significant at 0.05 


\begin{tabular}{|c|c|c|c|c|c|}
\hline Variables & $\begin{array}{l}\text { Inconvenient } \\
\text { n (\%) }\end{array}$ & $\begin{array}{l}\text { Expensive } \\
\mathrm{n}(\%)\end{array}$ & $\begin{array}{l}\text { Painful n } \\
(\%)\end{array}$ & $\begin{array}{l}\text { Can't } \\
\text { do it } \\
\text { age } \\
\text { n (\%) }\end{array}$ & $\begin{array}{l}\text { Necessary in hypoglycemic } \\
\text { condition } \\
\mathrm{n}(\%)\end{array}$ \\
\hline $\begin{array}{l}\text { Higher } \\
\text { Education }\end{array}$ & $\begin{array}{l}19 \\
(14.6 \%)\end{array}$ & $\begin{array}{l}23 \\
(17.6 \%)\end{array}$ & $\begin{array}{l}21 \\
(15.7 \%)\end{array}$ & $\begin{array}{l}20 \\
(16.0 \%)\end{array}$ & $\begin{array}{l}25 \\
(19.2 \%)\end{array}$ \\
\hline P-value & 0.100 & 0.069 & 0.288 & 0.937 & 0.621 \\
\hline Time Since D & gnosis of Diabe & & & & \\
\hline $\begin{array}{l}\text { less than } 05 \\
\text { years }\end{array}$ & $\begin{array}{l}48 \\
(36.9 \%)\end{array}$ & $\begin{array}{l}49 \\
(37.4 \%)\end{array}$ & $\begin{array}{l}53 \\
(39.6 \%)\end{array}$ & $\begin{array}{l}48 \\
(38.4 \%)\end{array}$ & $\begin{array}{l}55 \\
(42.3 \%)\end{array}$ \\
\hline $\begin{array}{l}\text { More than } \\
05 \\
\text { Years }\end{array}$ & $\begin{array}{l}82 \\
(63.1 \%)\end{array}$ & $\begin{array}{l}82 \\
(62.6 \%)\end{array}$ & $\begin{array}{l}81 \\
(60.4 \%)\end{array}$ & $\begin{array}{l}77 \\
(61.6 \%)\end{array}$ & $\begin{array}{l}75 \\
(57.7 \%)\end{array}$ \\
\hline P-value & 0.508 & 0.830 & 0.600 & 0.907 & 0.152 \\
\hline
\end{tabular}


Table 4

STRATIFICATION OF POTENTIAL CONFOUNDERS AND FACILITATORS TO SMBG:

\begin{tabular}{|c|c|c|c|c|c|}
\hline Variables & $\begin{array}{l}\text { experiencing } \\
\text { hypoglycemic } \\
\text { symptoms }\end{array}$ & $\begin{array}{l}\text { effect of } \\
\text { dietary } \\
\text { changes }\end{array}$ & $\begin{array}{l}\text { please your } \\
\text { physician }\end{array}$ & $\begin{array}{l}\text { family } \\
\text { motivation }\end{array}$ & $\begin{array}{l}\text { fear of } \\
\text { complications } \\
\text { of diabetes }\end{array}$ \\
\hline \multicolumn{6}{|c|}{ Age of Participants in Years } \\
\hline \multirow[t]{2}{*}{21 to 35} & 9 & 12 & 10 & 10 & 20 \\
\hline & $(6.7 \%)$ & $(9.3 \%)$ & $(7.4 \%)$ & $(7.6 \%)$ & $(9.8 \%)$ \\
\hline \multirow[t]{2}{*}{36 to 50} & 59 & 49 & 54 & 61 & 86 \\
\hline & $(43.7 \%)$ & $(38.0 \%)$ & $(39.7 \%)$ & $(46.2 \%)$ & $(42.0 \%)$ \\
\hline \multirow{2}{*}{$\begin{array}{l}\text { More than } \\
50\end{array}$} & 67 & 68 & 72 & 61 & 99 \\
\hline & $(49.6 \%)$ & $(52.7 \%)$ & $(52.9 \%)$ & $(46.2 \%)$ & $(48.3 \%)$ \\
\hline P-value & 0.558 & 0.120 & 0.172 & 0.796 & 0.110 \\
\hline \multicolumn{6}{|l|}{ Gender } \\
\hline \multirow[t]{2}{*}{ Male } & 72 & 63 & 68 & 66 & 103 \\
\hline & $(53.3 \%)$ & $(48.8 \%)$ & $(50.0 \%)$ & $(50.0 \%)$ & $(50.2 \%)$ \\
\hline \multirow[t]{2}{*}{ Female } & 63 & 66 & 68 & 66 & 102 \\
\hline & $(46.7 \%)$ & $(51.2 \%)$ & $(50.0 \%)$ & $(50.0 \%)$ & $(49.8 \%)$ \\
\hline P-value & 0.506 & 0.412 & 0.639 & 0.650 & 0.465 \\
\hline \multicolumn{6}{|c|}{ Educational Status } \\
\hline \multirow{2}{*}{$\begin{array}{l}\text { Not } \\
\text { educated }\end{array}$} & 13 & 12 & 16 & 10 & 17 \\
\hline & $(9.6 \%)$ & $(9.3 \%)$ & $(11.8 \%)$ & $(7.6 \%)$ & $(8.3 \%)$ \\
\hline \multirow[t]{2}{*}{ Primary } & 23 & 19 & 16 & 18 & 32 \\
\hline & $(17.0 \%)$ & $(14.7 \%)$ & $(11.8 \%)$ & $(13.6 \%)$ & $(15.6 \%)$ \\
\hline \multirow[t]{2}{*}{ Secondary } & 36 & 38 & 36 & 42 & 61 \\
\hline & $(26.7 \%)$ & $(29.5 \%)$ & $(26.5 \%)$ & $(31.8 \%)$ & $(29.8 \%)$ \\
\hline \multirow[t]{2}{*}{ Intermediate } & 38 & 40 & 46 & 37 & 61 \\
\hline & $(28.1 \%)$ & $(31.0 \%)$ & $(33.8 \%)$ & $(28.0 \%)$ & $(29.8 \%)$ \\
\hline Higher & 25 & 20 & 22 & 25 & 34 \\
\hline Education & $(18.5 \%)$ & $(15.5 \%)$ & $(16.2 \%)$ & $(18.9 \%)$ & $(16.6 \%)$ \\
\hline
\end{tabular}




\begin{tabular}{|llllll|}
\hline Variables & $\begin{array}{l}\text { experiencing } \\
\text { hypoglycemic } \\
\text { symptoms }\end{array}$ & $\begin{array}{l}\text { effect of } \\
\text { dietary } \\
\text { changes }\end{array}$ & $\begin{array}{l}\text { please your } \\
\text { physician }\end{array}$ & $\begin{array}{l}\text { family } \\
\text { motivation }\end{array}$ & $\begin{array}{l}\text { fear of } \\
\text { complications } \\
\text { of diabetes }\end{array}$ \\
\hline P-value & 0.320 & 0.927 & 0.174 & 0.507 & 0.401 \\
\hline Time Since Diagnosis of Diabetes & & & & \\
\hline $\begin{array}{l}\text { less than } 05 \\
\text { years }\end{array}$ & 54 & 50 & 49 & 51 & 75 \\
\hline $\begin{array}{l}\text { More than } \\
\text { 55 }\end{array}$ & 81 & $(30.0 \%)$ & $(36.0 \%)$ & $(38.6 \%)$ & $(36.6 \%)$ \\
Years & $(60.0 \%)$ & 79 & 87 & 81 & 130 \\
\hline P-value & 0.494 & $(61.2 \%)$ & $(64.0 \%)$ & $(61.4 \%)$ & $(63.4 \%)$ \\
\hline
\end{tabular}

\section{Discussion}

This study observed the barriers and facilitators of self- blood glucose monitoring practices among Type 2 diabetes patients attending family medicine clinics in a tertiary care hospital in Karachi Pakistan. The study found out that about $30.2 \%$ were adherent to self-monitoring of blood glucose. The major barriers that were identified were mainly related to cost, fear of needles and pain, cost of test (strips and needles), inconvenience. The facilitators were: experiencing hypoglycemic symptoms, desire to see the effects of dietary changes, desire to please the physician, and family motivation. A qualitative study conducted in Kuala Lumpur Malaysia on 15 individuals reported similar barriers and facilitators to SMBG as identified in the current study (19). The frequency observed in the current study is relatively low as compared to the Western World. A study conducted in Spain, found that the adherence to SMBG was $61.6 \%$, this is 2 times higher as reported by the current study (21). Another study from Pittsburgh USA on 21 Family physicians reported that at least 50 to $70 \%$ of their patients are adherent to SMBG (22). In Malaysia, a hospital reported that $66 \%$ of the T2DM patients practiced SMBG (23). However, the proportion of SMBG observed in the current study is comparable to other South Asian countries. This discrepancy in the proportion of SMBG can be due to the fact that the previous studies conducted on SMBG have varied in terms of their methodology, populations and format of SMBG. Moreover, Low SMBG usage may be due to inadequate counseling as patients are not aware of the specific aspects of self-monitoring such as how, when and what to do with their SMBG results(24).

\section{FACILITATORS FOR SMBG:}

In the study over half of the participants (52.9\%) responded that they do SMBG because of the fear or experiencing hypoglycemic situation. It is reported that the feelings associated with hypoglycemic episodes can lead to fear and anxiety in patients with diabetes and this fear can influence the patients to manage their diabetes, to avoid future episodes of hypoglycemia (25). The most common way of 
handling hypoglycemia which diabetics usually do is to do life style modifications and to see the effect of it, they move to SMBG (25-27). Though the association between fear of hypoglycemia and glycemic control is not fully established, and lack of any such association has been reported by numerous studies $(28,29)$. In the current study one of the major facilitators to SMBG was found to be family motivation (51.8\%). A study conducted on 22 African American T2DM patients', results were consistent with our study that indeed family support is an important facilitator of self-management of T2DM(18). The participants responded that family and friends helped participants to make healthy food choices and decisions regarding diabetes management and were identified as the major source of support for the participant (18). A systematic review of 22 studies (30) regarding management of diabetes also concluded that family motivation is a key factor in self-management of diabetes especially for South Asian families because of the cultural norms and traditions (30-32).

\section{Barriers To Smbg:}

In the study over half of the participants who were practicing SMBG reported that the cost of needles, strip, and glucometer is a barrier to SMBG. This is consistent with other studies which report similar findings (33-35). In Pakistan, there are no subsidies for test strips and needles. In United States of America test strips are reimbursed for the diabetics, even then the patients reported that SMBG was costly. A study conducted in 2007 by Khowaja et al reported that the annual mean direct cost for each person with diabetes was estimated to be Pakistani rupees 11,580 (US\$197) (36). Medicines accounted for the direct cost (46\%), followed by laboratory investigations (32\%) (36). In the study large number of participants had an average house hold income between PKR 20,000 to 50,000; this may be a reason of why only $30 \%$ of the patients were practicing SMBG. The high cost is one of the major barriers of SMBG (37). Studies have reported that higher costs have been associated with poor adherence to SMBG (18, 19). It has been concluded that the costs associated with diabetes complications and the number and overall duration of hospitalizations (38-39) also adds up the economic burden on the patients as well as the health care system.

The results of the current study shows that inconvenience is also one of the barriers for SMBG as the patients are not fully aware of the process to do SMBG $(40,41)$. This lack of awareness causes patients to not practice SMBG (42). A study conducted by Laranjo et al among Portuguese T2DM patients on the facilitators and barriers expectations in the self-management of type 2 diabetes reported that participants expressed the need for more information about type 2 DM (20). Some expressed concern that they wanted to learn more about how to self-manage their disease, but it was hard for them to find the information (20). A systematic review of 20 studies revealed that patients wanted to know more about diabetes, knowledge and communication with the healthcare provider was a significant barrier to receiving and understanding diabetes education (43). The study results are similar to another study conducted in Chennai India on 153 patients which revealed that only 37 (24.1\%) patients were aware about the SMBG and have been following self-blood glucose monitoring appropriately (28).

\section{Conclusion}


This study highlights the major barriers and facilitators to self-monitoring of blood glucose. Strategies should be developed to overcome these barriers as identified in the current study. Assessment of blood glucose control is a critical component of diabetes treatment and management. It can motivate patients to become active participants in their own care. Health Care providers should play a major role; that is to communicate and educate the patients about the advantages of SMBG. Physicians should educate and encourage patients towards SMBG. Moreover, availability of a diabetes educator in every hospital in Pakistan is an essential step to educate the general public on self- monitoring of blood glucose.

\section{Abbreviations}

SMBG $=$ Self-Monitoring of Blood Glucose

AKUH= Aga Khan University Hospital

IDF= International Diabetic Federation

T2DM= Type 2 Diabetes Mellitus

DCCT= Diabetes Control and Complications Trial

WHO= World Health Organization

SPSS $=$ Statistical Package for the Social Sciences

\section{Declarations}

\section{Ethics approval and consent to participate}

The current study was approved from the Institutional ethical review committee of Aga Khan University Hospital Karachi. A verbal and written consent was taken from the participants

\section{Consent for publication}

Not Applicable

\section{Availability of data and materials}

All the data generated or analyzed during this study are included in this published article

\section{Competing Interest}

The Authors declare that they have no any competing interest

\section{Funding}

This study is self-funded 
Authors' contribution

WA and AH, MK, FS, EM involved in conception or design of work and result analysis

MK, AA, ZA, NB, AH, DJM and SL involved in data interpretation and review process

AH, EM, SL, DJM, FS, AA and NB involved in data collection, drafting of the work and statistical analysis

All author read and approved the manuscript

\section{Acknowledgement}

Not Applicable

\section{References}

1. Ogurtsova K, da Rocha Fernandes J, Huang Y, Linnenkamp U, Guariguata L, Cho NH, et al. IDF Diabetes Atlas: Global estimates for the prevalence of diabetes for 2015 and 2040. Diabetes Res Clin Pract. 2017;128:40-50.

2. Ogurtsova K, da Rocha Fernandes JD, Huang Y, Linnenkamp U, Guariguata L, Cho NH, et al. IDF Diabetes Atlas: Global estimates for the prevalence of diabetes for 2015 and 2040. Diabetes Res Clin Pract. 2017;128:40-50.

3. Zimmet P, Alberti KG, Magliano DJ, Bennett PH. Diabetes mellitus statistics on prevalence and mortality: facts and fallacies. Nature Reviews Endocrinology. 2016;12(10):616.

4. Nanditha A, Ma RC, Ramachandran A, Snehalatha C, Chan JC, Chia KS, et al. Diabetes in Asia and the Pacific: implications for the global epidemic. Diabetes Care. 2016;39(3):472-85.

5. Akhtar S, Khan Z, Rafiq M, Khan A. Prevalence of Type II diabetes in District Dir Lower in Pakistan. Pakistan journal of medical sciences. 2016;32(3):622.

6. Harashima S-i, Nishimura A, Ikeda K, Wang Y, Liu Y, Inagaki N. Once Daily Self-Monitoring of Blood Glucose (SMBG) Improves Glycemic Control in Oral Hypoglycemic Agents (OHA)-Treated Diabetes: SMBG-OHA Follow-Up Study. J Diabetes Sci Technol. 2016;10(2):378-82.

7. Rhee E-J. Diabetes in Asians. Endocrinology Metabolism. 2015;30(3):263-9.

8. Ranasinghe $P$, Mathangasinghe $Y$, Jayawardena R, Hills A, Misra A. Prevalence and trends of metabolic syndrome among adults in the asia-pacific region: a systematic review. BMC Public Health. 2017;17(1):101.

9. Control TD, Group CDR. Effect of intensive therapy on the development and progression of diabetic nephropathy in the Diabetes Control and Complications Trial. Kidney Int. 1995;47(6):1703-20.

10. Young LA, Buse JB, Weaver MA, Vu MB, Mitchell CM, Blakeney T, et al. Glucose self-monitoring in non-insulin- treated patients with type 2 diabetes in primary care settings: a randomized trial. JAMA internal medicine. 2017;177(7):920-9. 
11. Bolinder J, Antuna R, Geelhoed-Duijvestijn P, Kröger J, Weitgasser R. Novel glucose-sensing technology and hypoglycaemia in type 1 diabetes: a multicentre, non- masked, randomised controlled trial. The Lancet. 2016;388(10057):2254-63.

12. Haak T, Hanaire H, Ajjan R, Hermanns N, Riveline J-P, Rayman G. Flash glucose-sensing technology as a replacement for blood glucose monitoring for the management of insulin-treated type 2 diabetes: a multicenter, open-label randomized controlled trial. Diabetes Therapy. 2017;8(1):55-73.

13. Heinemann L, Deiss D, Siegmund T, Schlüter S, Naudorf M, von Sengbusch S, et al. Practical recommendations for glucose measurement, glucose monitoring and glucose control in patients with type 1 or type 2 diabetes in Germany. Exp Clin Endocrinol Diabetes. 2018;126(07):411-28.

14. Charity KW, Kumar AM, Hinderaker SG, Chinnakali P, Pastakia SD, Kamano J. Do diabetes mellitus patients adhere to self-monitoring of blood glucose (SMBG) and is this associated with glycemic control? Experiences from a SMBG program in western Kenya. Diabetes Res Clin Pract. 2016;112:37-43.

15. Wong JC, Foster NC, Maahs DM, Raghinaru D, Bergenstal RM, Ahmann AJ, et al Response to Comment on Wong et al. Real-Time Continuous Glucose Monitoring Among Participants in the T1D Exchange Clinic Registry. Diabetes Care 2014; 37: 2702-2709. Diabetes care. 2015;38(4):e61-e.

16. Lim S, Kang SM, Kim KM, Moon JH, Choi SH, Hwang H, et al. Multifactorial intervention in diabetes care using real-time monitoring and tailored feedback in type 2 diabetes. Acta diabetologica. 2016;53(2):189-98.

17. Gao L, Ji L, Su Q, Feng B, Shan Z, Hu R, et al. Impact of structured self-monitoring of blood glucose on the quality of life of insulin-treated Chinese patients with type 2 diabetes-mellitus: Results from the COMPASS study. Diabetes Res Clin Pract. 2016;112:88-93.

18. Byers D, Garth K, Manley D, Chlebowy D. Facilitators and barriers to Type 2 diabetes selfmanagement among rural African American adults. Journal of Health Disparities Research Practice. 2016;9(1):9.

19. Ong WM, Chua SS, Ng CJ. Barriers and facilitators to self-monitoring of blood glucose in people with type 2 diabetes using insulin: a qualitative study. Patient Prefer Adherence. 2014;8:237.

20. Laranjo L, Neves AL, Costa A, Ribeiro RT, Couto L, Sá AB. Facilitators, barriers and expectations in the self- management of type 2 diabetes-a qualitative study from Portugal. European Journal of General Practice. 2015;21(2):103-10.

21. Vidal MF, Jansà MM, Galindo MR, Penalba MM. Factors associated to adherence to blood glucose self-monitoring in patients with diabetes treated with insulin. The dapa study. Endocrinologia diabetes y nutricion. 2018;65(2):99-106.

22. Havele SA, Pfoh ER, Yan C, Misra-Hebert AD, Le P, Rothberg MB. Physicians' views of self-monitoring of blood glucose in patients with type 2 diabetes not on insulin. The Annals of Family Medicine. 2018;16(4):349-52.

23. Sham SYZ, Thambiah SC, Samsudin IN, Chuan NO, Wei YS, Razmin NI. Practice Of Self-Monitoring Blood Glucose Among Insulin-treated Diabetic Patients In Hospital Serdang. Malaysian Journal of 
Medicine Health Sciences. 2016;12(2):38-44.

24. MANROA P, KRUPA DOSHI M. Self-monitoring of blood glucose: Advice for providers and patients. Cleveland clinic journal of medicine. 2016;83(5):355.

25. Al-Sahouri A, Merrell J, Snelgrove S. Barriers to good glycemic control levels and adherence to diabetes management plan in adults with Type-2 diabetes in Jordan: a literature review. Patient Prefer Adherence. 2019;13:675.

26. Agesen RM, Kristensen PL, Beck-Nielsen H, Nørgaard K, Perrild H, Jensen T, et al. Effect of Insulin Analogs on Frequency of Non-Severe Hypoglycemia in Patients with Type 1 Diabetes Prone to Severe Hypoglycemia: Much Higher Rates Detected by Continuous Glucose Monitoring than by SelfMonitoring of Blood Glucose-The HypoAna Trial. Diabetes technology therapeutics. 2018;20(3):247-56.

27. Hermanns N, Ehrmann D, Kulzer B. Continuous glucose monitoring-based technologies in hypoglycaemia- prone patients with type 1 diabetes. The lancet Diabetes endocrinology. 2019;7(6):419-21.

28. Krishnan V, Thirunavukkarasu J. Assessment of knowledge of self blood glucose monitoring and extent of self titration of anti-diabetic drugs among diabetes mellitus patients-a cross sectional, community based study. Journal of clinical diagnostic research: JCDR. 2016;10(3):FC09.

29. Fidler C, Elmelund Christensen T, Gillard S. Hypoglycemia: an overview of fear of hypoglycemia, quality-of-life, and impact on costs. Journal of medical economics. 2011;14(5):646-55.

30. Vatanasomboon

Pamungkas R, Chamroonsawasdi K. Vatanasomboon.

31. P. A systematic review: family support integrated with diabetes self-management among uncontrolled type II diabetes mellitus patients. Behav Sci. 2017;7(3):62.

32. Dogru A, Ovayolu N, Ovayolu O. The effect of motivational interview persons with diabetes on selfmanagement and metabolic variables. JPMA. 2019;69(294).

33. Shahar S, Fakhruddin NNINM, Hui KJ, Suhaimi NFS, Zulkepli NYF, Roslan R, et al. Family support and self- motivation influence dietary compliance and glycaemic control among type 2 diabetes mellitus outpatients. Jurnal Sains Kesihatan Malaysia (Malaysian Journal of Health Sciences). 2016;14(2).

34. Xie Y, Agiro A, Bowman K, DeVries A. Lowering cost share may improve rates of home glucose monitoring among patients with diabetes using insulin. Journal of managed care specialty pharmacy. 2017;23(8):884-91.

35. Klatman EL, Jenkins AJ, Ahmedani MY, Ogle GD. Blood glucose meters and test strips: global market and challenges to access in low-resource settings. The lancet Diabetes endocrinology. 2019;7(2):150-60.

36. Ugwu ET, Orjioke CJ, Young EE. Self monitoring of blood glucose among patients with type 2 diabetes mellitus in eastern Nigeria: Need for multi-strategic interventions. Curr Diabetes Rev. 2018;14(2):175-81. 
37. Khowaja LA, Khuwaja AK, Cosgrove P. Cost of diabetes care in out-patient clinics of Karachi. Pakistan BMC health services research. 2007;7(1):189.

38. Walker IF, Garbe F, Wright J, Newell I, Athiraman N, Khan N, et al. The economic costs of cardiovascular disease, diabetes mellitus, and associated complications in South Asia: a systematic review. Value in health regional issues. 2018;15:12-26.

39. Afroz A, Chowdhury HA, Shahjahan M, Hafez MA, Hassan MN, Ali L. Association of good glycemic control and cost of diabetes care: experience from a tertiary care hospital in Bangladesh. Diabetes Res Clin Pract. 2016;120:142-8.

40. Mohan V, Mapari JA, Karnad PD, Mann JS, Maheshwari VK. Reduced diabetes mellitus-related comorbidities by regular self-monitoring of blood glucose: Economic and quality of life implications. Indian journal of endocrinology metabolism. 2018;22(4):461.

41. Morera J. Insulin Injection and Blood Glucose Meter Systems. Handbook of Diabetes Technology: Springer; 2019. p. 3-21.

42. Shlomowitz A, Feher MD. Anxiety associated with self monitoring of capillary blood glucose. British Journal of Diabetes. 2014;14(2):60-3.

43. Mehmet S, Hussey C, Ibrahim S. Patients' perceptions of injecting insulin and self-monitoring of blood glucose in the presence of others. Practical Diabetes. 2015;32(2):59-63.

44. Eliacin J, Salyers MP, Kukla M, Matthias MS. Factors influencing patients' preferences and perceived involvement in shared decision-making in mental health care. Journal of Mental Health. 2015;24(1):24.

\section{Supplementary Files}

This is a list of supplementary files associated with this preprint. Click to download.

- Formula1.pdf

- AdditionalfileQuestinnareBMC.docx 